\title{
Correction
}

\author{
LEORA DAHAN KATZ (D)
}

\section{CORRECTION TO: RESPONSE RETRIBUTIVISM: DEFENDING THE DUTY TO PUNISH}

Unfortunately, in the original publication of the article, under the heading 'B. Dissociation' second paragraph, 5th sentence was published incorrectly. The corrected sentence should read as 'While what one is rejecting is the disrespect that underlies the wrongdoer's action and not the wrongdoer per se, what is required is not a rejection of the general act type, independent of the wrongdoer's involvement, but a rejection of the wrongdoer's devaluative action, which directs the negative reaction not at an abstract possibility of disrespect but at the wrongdoer in virtue of his authorship of such disrespect'.

The original article has been corrected.

Hebrew University of Jerusalem, Jerusalem, Israel

E-mail: leora.dahankatz@mail.huji.ac.il

Publisher's Note Springer Nature remains neutral with regard to jurisdictional claims in published maps and institutional affiliations.

The original article can be found online at https://doi.org/10.1007/s10982-020-09386-3. 